\title{
UNIDADES DE CONSERVAÇÃO: UMA DISCUSSÃO TEÓRICA Ã LUZ DOS CONCEITOS DE TERRITÓRIO E DE POLÍTICAS PÚBLICAS
}

\author{
LUIZ RENATO VALLEJO ${ }^{1}$ \\ Universidade Federal Fluminense
}

\section{APRESENTAÇÃO}

Um dos aspectos inerentes à discussão sobre Ordenamento Territorial e Ambiental é a questão da criação e gestão das unidades de conservação, áreas naturais protegidas pelo poder público e/ou pela iniciativa privada, destinadas à conservação da biodiversidade e outros fins.

Dentro desse contexto, foram selecionadas duas categorias conceituais: o "território" e as "políticas públicas ". Objetiva-se, com isso, consolidar um suporte teórico para desenvolvimento do projeto de doutoramento envolvendo o estudo de três Parques Estaduais no Rio de Janeiro (Desengano, Tiririca e Ilha Grande), suas características e avaliação das condições de conservação, em relação ao poder público e comunidades locais.

Em linhas gerais, podemos dizer que, a priori, o conceito de território abrange desde as questões ligadas à sobrevivência, e que envolvem as relações com o substrato material, até os processos de manutenção, consolidação e expansão dos espaços dominados, ou seja, as relações de poder. Há nisso um esforço transdisciplinar de se buscar a compreensão dos mecanismos que levam à própria organização espacial, em seu sentido mais amplo. $\mathrm{O}$ estudo das unidades de conservação contempla a discussão conceitual do território sob várias abordagens (biológica, cultural e econômica), além da possibilidade de se tratar também do problema da desterritorialização, tão importante no contexto histórico e contemporâneo.

A criação das unidades de conservação no mundo atual vem se constituindo numa das principais formas de intervenção governamental, visando reduzir as perdas da biodiversidade face à degradação ambiental imposta pela sociedade (desterritorialização das espécies da flora e fauna). Entretanto, esse processo tem sido acompanhado por conflitos e impactos decorrentes da desterritorialização de grupamentos sociais (tradicionais ou não) em várias partes do mundo.

$\mathrm{O}$ crescimento da consciência diante das questões ecológicas globais ampliou a participação popular em relação à qualidade de vida humana e o meio ambiente, representando outro aspecto relevante na análise das questões pertinentes às unidades de conservação. Portanto, vem aumentando as pressões junto aos governos para a constituição de políticas conservacionistas. A formação de uma rede em escala mundial e das redes nacionais, enquanto produto da expansão da consciência ambientalista, tem contribuído para aumento do número e extensão das áreas protegidas.

Ao mesmo tempo, para consolidação das funções sociais e ambientais relativas às unidades de conservação, há necessidade de implementação de estratégias políticas e gerenciais por parte dos governos a fim de se atingir determinadas metas de ordenamento territorial. Esse esforço de ordenamento envolve múltiplos atores no processo: as comunidades biológicas, as comunidades humanas locais, organizações governamentais e não governamentais, usuários e a iniciativa

1 Doutor em Geografia pela Universidade Federal Fluminense - Mestre em Ciências — Geografia, Bacharel em Ciências Biológica - Ecologia, Professor Adjunto IV do Dept ${ }^{\circ}$. de Geografia da UFF. 
privada, logo, se apresenta de forma complexa e é passível de ser conflituoso. A atuação dos governos, como acontece no Brasil, tem promovido a criação das unidades de conservação, mas não se pode dizer o mesmo em relação ao gerenciamento. Por isso, as unidades de conservação no Brasil têm sido caracterizadas por certos autores como "ficções jurídicas" e "parques de papel" (MORSELLO, 1999; BRITO, 1998a).

Inicialmente, será apresentada uma síntese sobre a história das unidades de conservação, relatando os. fatos mais importantes que propiciaram a consolidação de uma política de conservação da biodiversidade em escala mundial. Posteriormente, discutiremos a temática da conservação de espaços silvestres à luz do conceito de território, considerando desde a abordagem biológica (mais tradicional) até as abordagens sociais do conceito.

Num segundo momento, serão tratadas questões objetivas e subjetivas relacionadas à conservação da biodiversidade e à criação de unidades de conservação, considerando a necessidade de agregação de valores.

Finalmente, teremos uma apresentação conceitual sobre políticas públicas e um panorama de como esse assunto tem sido tratado em relação às unidades de conservação brasileiras.

\section{UNIDADES DE CONSERVAÇ̃̃O: HISTÓRIA E GLOBALIZAÇÃO DE POLÍTICAS DE CONSERVAÇÃO}

\section{As tradições}

A delimitação de áreas com vistas à preservação de seus atributos naturais evoluiu ao longo da história a partir de suas raízes em atos e práticas das primeiras sociedades humanas (MILLER, 1997). As necessidades de uso imediato e futuro dos recursos envolvendo animais, água pura, plantas medicinais e outras matérias-primas, justificavam a manutenção desses sítios, além de se constituírem em espaços de preservação de mitos e ocorrências históricas. Tabus, éditos reais e mecanismos sociais comunitários funcionavam - e ainda funcionam em muitos casos - como reguladores do acesso e uso dessas áreas especiais (MILLER, 1997).

Mesmo na atualidade, há casos como dos índios Caiapós, perto do Rio Xingu na Amazônia, que mantêm zonas tampão entre os lotes agrícolas e a floresta ao redor, para resguardar plantas medicinais e animais predadores que controlam naturalmente as populações daninhas. Também são preservados corredores naturais de matas antigas entre glebas que servem como reservas biológicas e facilitam o reflorestamento de campos antigos (POSEY, 1988, apud MILLER).

Além da delimitação de espaços especiais relacionados mais diretamente com a sobrevivência de populações tradicionais, existem registros históricos bem remotos envolvendo outras finalidades. É o caso da criação de reservas de caça e das leis de proteção de áreas surgidas no Irã em tomo de 5.000 a.C. (OLIVEIRA, 1999). As primeiras evidências sobre do conceito de parque foram encontradas na Mesopotâmia, regiões da Assíria e Babilônia, possivelmente em decorrência da situação de escassez das populações animais (BENNETT, 1983).

No ocidente essa prática é bem mais recente, remontando à Idade Média, quando as classes dominantes da antiga Roma e da Europa Medieval destinavam áreas para seu uso exclusivo e alguns reis separavam pequenas áreas para proteção de determinadas espécies (ROCHA, 2002). $\mathrm{Na}$ Inglaterra existem registros sobre a existência dessas áreas já nos tempos da invasão Saxônica, em 1066 (BENNETT). Na Suíça, em 1569, foi criada uma reserva para proteger o antílope europeu e no séc. XVIII, a França criou Parques Reais, que chegaram a ser abertos ao público. Na Inglaterra, séc. XIX, foram criadas reservas conhecidas como "Forest", que ocuparam parte significativa do território inglês e eram destinadas à caça (QUINTAO, 1983).

A preservação da maioria dessas áreas relacionava-se com os interesses da realeza e da aristocracia rural. O objetivo principal era a manutenção dos recursos faunísticos e de seus respectivos habitats visando o exercício da caça ou, então, a proteção de recursos florestais com fins de uso imediato ou futuro. $\mathrm{O}$ objetivo não era a subsistência nem havia qualquer sentido social mais amplo como, por exemplo, lazer e recreação para o público em geral. 
Com a revolução industrial vieram transformações políticas, culturais, econômicas, sociais e ambientais. A acumulação capitalista e expansão dos mercados foram fundamentais para essas mudanças. A agricultura tornou-se mais especializada para suprir as demandas da indústria Européia. No século XIX, as premissas capitalistas centradas nos significados da produção (terra, trabalho e capital) foram se consolidando e a economia clássica, ao tratar os recursos da Terra como mercadoria, considerava irrelevante a degradação ambiental. Tais idéias aliadas ao incremento industrial promoveram grande avanço da degradação dos recursos naturais e, concomitantemente, redução dos espaços nativos. Os problemas ambientais, além de atingir as colônias por conta da intensiva exploração de recursos, manifestavam-se também nas sedes dos próprios países industrializados (OLIVEIRA, 1998).

Desde o século XVIII, brotavam contestações a respeito dos direitos ilimitados do homem sobre a natureza (THOMAS, 1983, apud DIEGUES, 1993). Avanços da História Natural e, sobretudo, os problemas gerados pelo crescimento desordenado das cidades, acabaram contribuindo para a valorização da vida no campo e no mundo rural, onde reinava a calma de uma vida bucólica. A aristocracia fugia dos centros urbanos poluídos, a literatura e a pintura começaram a valorizar lugares de enlevo e fonte de renovação espiritual. Mas somente após a revolução industrial começaram a surgir movimentos mais abrangentes de proteção de áreas naturais com a finalidade de uso público. Esse fato deveu-se, possivelmente, ao crescente número de pessoas em rotinas de trabalho fabris que demandavam por espaços para recreação ao ar livre (Milano, 2000).

\section{Os primeiros parques públicos}

Foi nos Estados Unidos, ao final do séc. XIX, que se empregou efetivamente o conceito de parque nacional como área natural, selvagem, logo após o extermínio quase total das comunidades indígenas e a expansão das fronteiras para o oeste. Com a consolidação e urbanização acelerada do capitalismo americano, propunha-se reservar grandes áreas naturais a disposição das populações urbanas para fins de recreação. Nesse caso, o sentido de parque nacional veio acompanhado da noção de "wilderness" (vida natural/selvagem). Em 1872, após a realização de vários estudos, foi criada a primeira área com status de Parque Nacional do mundo, o de Yellowstone, passando a ser uma região reservada e proibida de ser colonizada, ocupada ou vendida segundo as leis americanas (MILLER, 1980, apud DIEGUES, 1993).

No processo de criação do PN de Yellowstone, prevaleceu uma perspectiva preservacionista que via nos parques nacionais a única forma de salvar pedaços da natureza de grande beleza contra os efeitos deletérios do desenvolvimento urbano-industrial. Ela se baseava nas conseqüências do capitalismo sobre o oeste selvagem, nos efeitos da mineração sobre rios e lagos americanos. Dessa forma, qualquer intervenção humana na natureza era vista de forma negativa. Desconsiderava-se que os índios americanos tinham vivido em harmonia com a natureza por milhares de anos. Para os preservacionistas americanos, todos os grupos sociais eram iguais e a natureza deveria ser mantida intocada das ações negativas da humanidade.

Esse modelo americano acabou se espalhando pelo mundo numa perspectiva dicotômica entre "povos" e "parques". Partindo-se do princípio de que a presença humana é sempre devastadora para a natureza, deixaram de ser considerados os diferentes modos de vida das chamadas "populações tradicionais" existentes em outros países como na América do Sul e África. Diegues (1993) enfatiza que essa postura preservacionista na criação de parques nacionais acabou gerando conflitos afetando populações de extrativistas, pescadores e índios, em países do Terceiro Mundo.

A criação de outros parques pelo mundo no Canadá (1885), na Nova Zelândia (1894), na Austrália e na África do Sul (ambos em 1898) seguiu o modelo de Yellowstone. Todos esses países viviam processos semelhantes ao americano, ou seja, de severos danos ao ambiente causados por empresas de migrantes europeus (QUINTÃO, 1993).

Com a virada do século $\mathrm{XX}$, parques e reservas similares foram sendo criados em vários países. Além da proteção de belezas cênicas admiráveis, a criação dos novos parques agregou outras motivações como a preservação da biodiversidade florística e faunística e dos bancos 
genéticos (GHIMIRE, 1993 apud BRITO, 2000b). Sob esse prisma, as áreas naturais protegidas passaram a servir também como laboratórios para a pesquisa básica em ciências biológicas. Como exemplo, temos a criação dos primeiros parques nacionais europeus na Suíça e Suécia. A perspectiva científica de criação de parques acabou reforçando a idéia de que a presença humana nessas áreas só deveria ser permitida em situações muito particulares e restritas. A criação de parques em áreas que já eram habitadas por populações tradicionais, ocasionou sua remoção, como no caso dos Maasai no Quênia, os $1 \mathrm{k}$ em Uganda e os pescadores artesanais no Canadá (WEST \& BRECHIN, 1991, apud BRITO, 2000b).

\section{O processo de mundialização das políticas de preservação e conservação}

Com a diversificação dos objetivos nos diferentes países e conseqüente aumento da complexidade do tema, foi necessário estabelecer conceitos e diretrizes mais gerais a nível mundial. Diversos encontros em escala mundial e continental ocorreram, destacando-se aqui:

> a Convenção para Preservação da Fauna e Flora em Estado Natural (Londres, 1933);

> a Convenção Panamericana de Proteção da Natureza e Preservação da Vida Selvagem do Hemisfério Oeste (Washington, 1940);

> o Congresso organizado pelo governo Francês e pela Organização das Nações Unidas para a Educação, Ciência e Cultura (UNESCO) em 1948, quando foi fundada a União Internacional para a Proteção da Natureza (UIPN), posteriormente denominada de União Internacional para a Conservação da Natureza (UICN), englobando agências governamentais e não-governamentais, e que passou a coordenar e iniciar trabalhos de cooperação internacional no campo da conservação da natureza;

$>$ As Assembléias Anuais da UICN, realizadas a partir de 1960; e

$>$ os I, II, III e IV Congressos Internacionais de Parques Nacionais, respectivamente nos EUA (Seattle, 1962 e Yellowstone, 1972) Indonésia (Bali, 1982) e Venezuela (Caracas, 1992).

A realização desses encontros resultou das várias mudanças conceituais e das perspectivas na criação e gestão das unidades de conservação pelo mundo, além de desempenharem um papel organizador e coordenador de políticas de conservação. Fora os parques, foram surgindo novas categorias de manejo como as Reservas Naturais, Monumentos Naturais, Reservas Silvestres, Reservas da Biosfera, etc. As perspectivas de criação também se diversificaram. Inicialmente, como já foi dito, prevalecia o interesse de proteção das áreas e de suas características naturais na forma de santuários ecológicos. Logo depois, vieram as pesquisas científicas, fortalecendo o ideal de isolamento dessas áreas. O desenvolvimento científico entre as décadas de 30 e 60 , paralelamente ao incremento dos impactos da extração de recursos naturais, atividades industriais e redução da biodiversidade mundial, motivou o surgimento de uma nova perspectiva para as unidades de conservação, que foi a da conservação ${ }^{2}$, estimulando o uso racional de recursos naturais e o manejo de espécies.

A partir do III Congresso Mundial de Parques Nacionais, em 1982, firmou-se uma nova estratégia em que os parques nacionais e outras unidades de conservação só teriam sentido com a elevação da qualidade de vida da população dos países em vias de desenvolvimento. Reafirmaram-se os direitos das sociedades tradicionais e sua determinação social, econômica, cultural e espiritual, recomendado-se aos responsáveis pelo planejamento e manejo das áreas protegidas que respeitassem a diversidade dos grupos étnicos e utilizassem suas habilidades. As decisões de manejo deveriam ser conjuntas com as autoridades, considerando-se a variedade de circunstâncias locais. Dessa forma questionou-se definitivamente a visão romântica das áreas de preservação como paraísos protegidos, um dos ideais norteadores da criação do Parque Nacional de Yellowstone.

2 Esclarecemos que a perspectiva conservacionista difere do preservacionsimo, na medida em que envolve a possibilidade de manejo das espécies e do ambiente em geral, ao passo que o preservacionsimo é mais protecionista. Por exemplo, o manejo reprodutivo de uma espécie ameaçada de extinção (conservação) pode recuperar sua densidade demográfica a ponto e salvá-la do extermínio, enquanto o simples isolamento (preservacionismo) poderia resultar também em seu desaparecimento. 
Vale destacar que durante o IV Congresso Internacional de Parques Nacionais (1986) foi divulgado que $86 \%$ dos Parques da América do Sul eram ocupados por populações permanentes. Recomendou-se maior respeito pelas populações tradicionais possuidoras de um conhecimento secular sobre os ecossistemas onde vivem, rejeitando estratégias de reassentamento em outras áreas e, sempre que possível, sua inserção na área do parque a ser criada.

Desde os anos 50 houve grande expansão no estabelecimento de áreas naturais protegidas. Até 1949 haviam apenas 407 áreas protegidas em todo o mundo e dados recentes do World Resources Institute (2000-01) informam a existência de 28.442 unidades de conservação terrestres (categorias I a V da UICN, 1994) ${ }^{3}$, perfazendo mais de 850 milhões de hectares dentro dos Sistemas Nacionais de Proteção (Tabela 1).

Tabela 1 - Áreas Naturais Protegidas a Nível Nacional e Internacional no Mundo (World Resources Institute, 2000-01)

\begin{tabular}{|c|c|c|c|c|c|c|c|}
\hline \multirow{3}{*}{ Continente } & \multicolumn{5}{|c|}{$\begin{array}{c}\text { Sistemas Nacionais de Proteção (Categorias de I a V } \\
\text { da IUCN) }{ }^{*}\end{array}$} & \multirow{2}{*}{\multicolumn{2}{|c|}{$\begin{array}{c}\begin{array}{c}\text { Áreas protegidas } \\
\text { resultantes de }\end{array} \\
\text { acordos } \\
\text { internacionais** }^{* *}\end{array}$}} \\
\hline & \multirow{2}{*}{$\begin{array}{l}\text { Número } \\
\text { total }\end{array}$} & \multirow{2}{*}{$\begin{array}{c}\text { Área } \\
(1000 \text { ha })\end{array}$} & \multirow{2}{*}{$\begin{array}{c}\% \text { da } \\
\text { Área de } \\
\text { ha }\end{array}$} & \multicolumn{2}{|c|}{$\begin{array}{l}\mathrm{N}^{\circ} \text { de Áreas com } \\
\text { pelo menos }\end{array}$} & & \\
\hline & & & & $\begin{array}{l}100.000 \\
\text { de há }\end{array}$ & 1 milhão & Número & $\begin{array}{c}\text { Área } \\
(1.000 \mathrm{ha})\end{array}$ \\
\hline $\begin{array}{l}\text { Ásia (excluindo o } \\
\text { Oriente Médio) }\end{array}$ & 2.421 & 148.692 & 6,0 & 210 & 20 & 129 & 21.625 \\
\hline Europa & 12.356 & 109.297 & 4,7 & 212 & 12 & 799 & 142.379 \\
\hline $\begin{array}{l}\text { Oriente Médio e } \\
\text { Norte da África }\end{array}$ & 518 & 25.863 & 2,1 & 25 & 5 & 74 & 25.539 \\
\hline $\begin{array}{l}\text { África } \\
\text { (Sul do Saara) }\end{array}$ & 1.005 & 146.904 & 6,0 & 202 & 33 & 142 & 83.478 \\
\hline $\begin{array}{l}\text { América do } \\
\text { Norte }\end{array}$ & 6.146 & 213.822 & 11,1 & 255 & 46 & 123 & 57.107 \\
\hline $\begin{array}{l}\text { América Central } \\
\text { e Caribe }\end{array}$ & 813 & 16.450 & 6,1 & 35 & 1 & 87 & 20.208 \\
\hline América do Sul & 1.116 & 131.663 & 7,4 & 202 & 26 & 87 & 70.882 \\
\hline Oceania & 4.056 & 60.784 & 7,1 & 109 & 11 & 90 & 56.067 \\
\hline $\begin{array}{l}\text { Países } \\
\text { Desenvolvidos }\end{array}$ & 23.397 & 405.509 & 7,2 & 617 & 71 & $\begin{array}{c}1 . \\
053\end{array}$ & 257.245 \\
\hline $\begin{array}{l}\text { Países em } \\
\text { Desenvolvimento }\end{array}$ & 5.045 & 446.002 & 5,8 & 633 & 83 & 478 & 222.870 \\
\hline Mundo & 28.442 & 851.511 & 6,4 & 1.250 & 154 & 1.536 & 479.118 \\
\hline
\end{tabular}

Para finalizar este tópico do trabalho, destacamos que os propósitos atuais a serem alcançados pela política mundial contemporânea de criação de unidades de conservação, no âmbito nas diferentes categorias de manejo (UICN, CPNAP, CMMC, 1994) são:

1. pesquisa científica;

2. proteção da vida selvagem;

3 Reserva Natural Estrita, Parque Nacional, Monumento Natural e Área de Manejo de Habitat ou de Espécies

* Não foram contabilizadas as áreas litorâneas e marinhas

* * Reserva da Biosfera, Sítios do Patrimônio Mundial e Áreas Úmidas de Importância Internacional 
3. preservação de espécies e da diversidade genética;

4. manutenção dos serviços de meio ambiente;

5. proteção de aspectos naturais e culturais específicos;

6. recreação e turismo;

7. educação;

8. uso sustentável de recursos de ecossistemas naturais; e

9. manutenção de atributos culturais tradicionais.

No Brasil, a Lei 9.985, de 18 de julho de 2000, estabeleceu o Sistema Nacional de Unidades de Conservação (SNUC), onde foram definidos critérios e normas para a implantação e gestão das unidades de conservação.

Os objetivos do SNUC, explicitados em seu art. $4^{\circ}$, praticamente coincidem com aqueles estabelecidos pela UICN.

\section{UNIDADES DE CONSERVAÇÃO E TERRITORIALIDADE: AS MULTIPLAS ABORDAGENS DO TEMA}

O conceito de território é empregado, tradicionalmente, pelas Ciências Naturais com ênfase no estudo da Ecologia das espécies e das populações naturais. As Ciências Sociais como as Ciências Políticas, a Antropologia e a Geografia, também se utilizam desse conceito. Nas Ciências Políticas, o território está intimamente relacionado com a formação do Estado, enquanto na Antropologia, o conceito é muito utilizado em relação às sociedades tradicionais, onde os vínculos espaciais são bastante pronunciados. No caso da Geografia que se caracteriza, fundamentalmente, como ciência de integração entre o espaço físico e os processos sociais, o território não poderia deixar de ser uma categoria geográfica das mais importantes a serem debatidas.

A abordagem teórica do estudo das unidades de conservação tem no conceito de território um grande espectro de possibilidades de discussão, tanto em relação ao chamado "mundo natural", quanto às questões que dizem respeito à sociedade, em geral, e grupamentos sociais, em particular. Além disso, os recentes debates sobre a problemática das unidades de conservação têm demandado uma aproximação entre as múltiplas abordagens do território.

A seguir, apresentaremos alguns conceitos e perspectivas na análise do território que servirão de base ao desenvolvimento de nossa discussão.

\section{A abordagem biológica}

Podemos dizer que está intimamente associada com o estudo das necessidades básicas de sobrevivência das múltiplas espécies que integram a complexa teia de relações dos ecossistemas. Ao empenhar-se pela sobrevivência, as espécies interagem entre si e com o meio físico, exercendo uma função no conjunto, que é o próprio ecossistema. Existe, nessa abordagem, uma visão sistêmica ${ }^{4}$, portanto funcionalista, pois cada indivíduo, assim como a própria espécie, desempenha um papel e, nesse contexto, emprega-se largamente o conceito de nicho ecológico, que:

Inclui não apenas o espaço físico ocupado por um organismo, mas também seu papel funcional na comunidade (como, por exemplo, sua posição na cadeia trófica) e sua posição nos gradientes ambientais de temperatura, umidade, $\mathrm{pH}$, solo e outras condições de existência... O nicho ecológico de um organismo depende não só de onde vive, mas também

4 Segundo Tricart, J (1977, apud FEEMA, 1992) sistema é “o conjunto de fenômenos que se processam mediante fluxos de matéria e energia. Esses fluxos originam relações de dependência mútua entre os fenômenos. Como conseqüência, o sistema apresenta propriedades que lhe são inerentes e diferem da soma das propriedades dos seus componentes. Uma delas é ter dinâmica própria, especifica do sistema" 
do que faz (como transforma energia, como se comporta e reage ao meio fisico e biótico e como o transforma) e de como é coagido por outras espécies (ODUM, E.P., 1972, apud FEEMA, 1992, p. 142).

Como extensão do conceito de nicho ecológico, fala-se em territorialidades. O próprio Odum, E.P.(1977, p. 137) assinala:

um padrão de conduta que resulta em competição intra-especifica por espaço e exerce um controle realmente efetivo sobre o tamanho da população, é conhecido como territorialidade; e é característico para muitas espécies de pássaros e alguns outros animais superiores". A territorialidade é interpretada, na maioria das vezes, como processo auto-regulador: “...mecanismo de controle natural de conduta conhecido como territorialidade, mediante o qual muitas espécies animais evitam o amontoamento e a pressão social (ODUM, E.P., 1972, p. 300).

No seio das comunidades naturais certas espécies e sua territorialidade são importantes para determinar a persistência de muitas outras. Elas afetam a organização da comunidade em um grau muito mais elevado do que se poderia prever, baseado apenas na quantidade de indivíduos ou em sua biomassa (TERBORG, 1976; JANZEN 1986, apud PRIMACK E RODRIGUES, 2001). São denominadas de espécies-chave e sua proteção é uma prioridade para os esforços da conservação, pois no caso dela desaparecer da área, outras espécies poderão também ser perdidas. Os predadores do topo da cadeia alimentar estão entre as espécies-chave mais óbvias, pois controlam as populações de herbívoros. Mesmo a eliminação de um pequeno número de predadores, pode resultar em mudanças dramáticas na vegetação e em grande parte na diversidade biológica (PIMM, 1991; MCLAREN e PETERSON, 1994, apud PRIMACK e RODRIGUES, 2001). Portanto, a eliminação de uma espécie-chave pode ocasionar um efeito em cascata, resultando na degradação de todo o ecossistema.

A delimitação das unidades de conservação é considerada em função de seu tamanho, pois, em geral, as grandes unidades dispõem de mais espécies do que as pequenas. Entretanto, uma área sozinha poderá não ser significativa tanto quanto a variedade de habitats e recursos que essa reserva contenha. Determinados habitats podem conter recursos-chave que, apesar de ocupar apenas uma pequena área, são necessários a muitas espécies da comunidade. Como exemplo, temos o caso de riachos e aguadas em áreas de Cerrado restritos a uma pequena área em relação à área total, mas que se constituem na única fonte de água superficial nesse ecossistema, tanto para plantas quanto para animais. Uma pequena praia deserta no litoral utilizada para deposição de ovos de tartarugas marinhas é outro exemplo de recurso-chave restrito a um habitat de pequenas proporções, mas da maior importância para a preservação daquela espécie marinha (PRIMACK e RODRIGUES, 2001).

O estudo da territorialidade no contexto das unidades de conservação é da mais alta importância, inclusive na definição da extensão geográfica mínima necessária à conservação das espécies e, também, para o entendimento dos processos que têm levado à sua desterritorialização.

\section{As abordagens sociais}

Apresentaremos agora, uma pequena seleção de enunciados atribuídos a autores que trabalham a questão do território sob o prisma das sociedades humana. Segundo Godelier:

"Designa-se por território uma porção da natureza e, portanto, do espaço sobre o qual uma determinada sociedade reivindica e garante a todos ou parte de seus membros direitos estáveis de acesso, de controle e de uso com respeito à totalidade ou parte dos recursos que ai se encontram que ela deseja e é capaz de explorar". Ou: "...denominaremos território a porção da natureza e do espaço que uma sociedade reivindica como o lugar em que seus membros encontrarão permanentemente as condições e os meios materiais de sua existência" 
(GODELIER, M., 1984, apud HAESBAERT, R., 2002).

Soja define territorialidade como

um fenômeno de comportamento associado à organização do espaço em esferas de influência ou em territórios nitidamente delimitados, que assumem características distintas e podem ser considerados, pelo menos em parte, como exclusivos de quem os ocupa e de quem os define. (SOJA, apud RONCAYOLO, 1986).

Trata-se pois de um conceito que pode ser inserido num campo simultaneamente extenso e unificado que integra espécies, atividades e níveis de percepção e de organização diferentes.

Raffestin, C. (1993) assinala que o

"território é o resultado de uma de ação conduzida por um ator sintagmático (que realiza um programa) em qualquer nível”.

O espaço é anterior ao território, pois o ator "territorializa" o espaço.

Lefebvre, H. (apud RAFFESTIN, 1993) exemplifica como se passa do espaço para o território citando o caso do território nacional: espaço físico, balizado, modificado, transformado pelas redes, circuitos e fluxos (rodovias, estradas de ferro, rotas aéreas, canais, circuitos bancários e comerciais, etc.). Nessa perspectiva, o território é um espaço onde se projetou o trabalho, seja energia e informação e, ao mesmo tempo, revela as relações marcadas pelo poder.

Naranjo, assinala que

o território é um espaço geográfico ocupado por um ser ou conjunto de seres, sobre o qual se manifestam as relações de sobrevivência e reprodução.(NARANJO, 2000)

Quando se atribui o conceito a um grupo humano complexo (um povo, uma nação, uma sociedade se converte em

um dos integrantes fundamentais de seu projeto comum; em suporte e recurso básico, âmbito de vida, paisagem própria e invariante na memória pessoal e coletiva. (NARANJO, 2000)

É o espaço geográfico em que se vive e que requer administração para o bem dos indivíduos e do conjunto da comunidade.

Um aspecto comum a todos esses enunciados é a existência de uma base material espacial sobre a qual estabelecem-se inúmeras relações com e entre os indivíduos, muitas delas biologicamente vitais. O balizamento geográfico, visível ou invisível, é outro aspecto marcante contido nesses conceitos, podendo estar associados a diferentes escalas de análise (individual, local, regional ou nacional). A manutenção e perpetuação do território dependem, fundamentalmente, de uma estrutura de poder seja num sentido mais geral, associado à capacidade de criar, destruir, consumir, preservar ou reparar (força/autoridade) ou no sentido atribuído por Marx, K. (apud HAESBAERT) como forças produtivas da natureza (fertilidade do solo, procriatividade do mundo animal, etc).

Haesbaert, ao elaborar uma análise sobre as diversas concepções de território, no âmbito das Ciências Sociais, assinala que elas podem ser agrupadas segundo certos referenciais teóricos. Existe, primeiramente, uma perspectiva materialista em que a ligação material entre território e natureza é explícita, ou seja, a natureza é antes de tudo uma fonte de recursos, "meios materiais de existência". Mesmo os antropólogos tão preocupados em enfatizar a dimensão cultural ou simbólica da sociedade, têm optado pela perspectiva material e HAESBAERT) cita como exemplo Godelier. O conceito anteriormente expresso por Naranjo, também dá ênfase à base material do território. Como vimos, essa avaliação é imprescindível para, discussão da abordagem biológica do conceito, pois qualquer espécie requer uma base material de sustentação. 
No estudo das sociedades tradicionais essa noção de território é bastante influenciada por suas experiências de vida, pois a principal fonte de recursos provém da natureza. E o caso do reconhecimento de valores especiais ligados aos sítios geográficos no passado e que ainda subsistem em muitas partes do mundo, inclusive no Brasil, e que eram acompanhados de medidas de proteção da fauna, da água pura, de plantas medicinais e de outras matérias-primas.

Como foi dito antes, essas experiências das sociedades mais tradicionais são precursoras das práticas atuais de conservação de recursos ambientais através de unidades de conservação, portanto uma prática territorial.

Outra perspectiva sobre o conceito de território apresentada por Haesbaert, inclui uma dimensão não material, ou seja, a existência de poderes invisíveis implícitos (ideal-simbólica). Há autores que enfatizam de forma mais intensa essa perspectiva, apesar de que mesmo entre aqueles que destacam a dimensão materialista do território, não se deixa de incorporar uma dimensão ideal ou de "apropriação simbólica".

Bonnemaison e Cambrézy (apud HAESBAERT, 2002) adotam essa perspectiva, onde o pertencimento ao território implica a representação da identidade cultural. Eles consideram que a abordagem materialista-utilitarista do território não dá conta dos principais conflitos do mundo contemporâneo. Por isso

"o território é primeiro um valor", pois "a existência e mesmo a imperiosa necessidade para toda a sociedade humana de estabelecer uma relação forte, ou mesmo uma relação espiritual com seu espaço de vida, parece claramente estabelecida" (BONNEMAISON e CAMBRÉZY, apud HAESBAERT, 2002)

Além disso:

O poder do laço territorial revela que o espaço está investido de valores não apenas materiais mas também éticos, espirituais, simbólicos e afetivos. E assim que o território cultural precede o território político e com ainda mais razão precede o espaço econômico. (BONNEMAISON e CAMBRÉZY, Apud HAESBAERT, 2002)

Nas sociedades pré-industriais e primitivas de caçadores e coletores havia uma ligação mais intensa pois o território, além de fonte de recursos, era sujeito a uma apropriação simbólicoreligiosa. Nas sociedades tradicionais, a natureza simbólica das relações sociais tinha um papel da maior significância na sua definição de território. A força de sua carga simbólica é tão grande que o território é passa a ser um "construtor de identidade, talvez o mais eficaz de todos" (BONNEMAISON e CAMBRÉZY , apud HAESBAERT, 2002)

No Brasil, existem diversos exemplos sobre o papel do imaginário popular dos povos da floresta, rios e lagos na formação e conservação dos territórios e que ilustram bem esse processo de "apropriação simbólica". Muitas representações míticas, além do valor explicativo, têm um sentido territorial e conservacionista. Câmara Cascudo (apud DIEGUES, 1997) relaciona a presença de diversas entidades mágicas que castigam os que destroem as florestas (Caipora/Curupira, Mãe da Mata, Boitatá), maltratam os animais da mata (Anhangá), matam os animais em épocas de reprodução (Tapiora), pescam mais que o necessário (Mãe d'Água), além de outros. Há um sentido de sacralização de algumas áreas em rios, estuários e florestas e que não devem ser utilizadas para fins econômicos e, nesses casos, a interdição religiosa contribui para conservação dos recursos naturais.

A preservação dos estoques de caça promovida por imperadores, reis e outros membros da aristocracia desde a antigüidade, exemplifica também a presença da materialidade e do simbolismo no territorialismo de criação dos primeiros parques e reservas. Segundo os fundamentos ecológicos que regem a dinâmica das populações naturais, os grandes predadores (e ao mesmo tempo, objeto de caça como os lobos, ursos, leões, etc), requerem um espaço territorial maior que as demais espécies, podendo se constituir num dos critérios de balizamento dessas reservas (PRIMACK, e RODRIGUES, 2001). O simbolismo se apresenta nas motivações de uso do território como o lazer (caça esportiva e jogos reais), preservação de animais sagrados e, por 
que não dizer, afirmação de poder territorial diante dos súditos e até de outras nações.

A criação do Parque Nacional de Yellowstone no final do séc. XIX, precursor de todas as unidades de conservação públicas contemporâneas, foi acompanhada de importantes motivações simbólicas, talvez mais fortes que as materiais. A publicação "Man and the Nature" de George Perkins (apud OLIVEIRA, 1999) estabeleceu uma perspectiva ecológica nova, iniciando uma intensa discussão sobre ambientalismo na sociedade americana. $\mathrm{O}$ movimento encontrou vários aliados entre os intelectuais americanos na busca de uma identidade cultural, incorporando valores conservacionistas para reforçar suas convicções sobre os valores nacionais americanos. $\mathrm{O}$ culto à natureza como prova da gratidão nacional começou justamente após a independência, com os intelectuais tentando reforçar a visão de um destino grande e glorioso para os Estados Unidos, a despeito da ausência de uma herança artística e literária. Pela primeira vez, os americanos argumentaram que os EUA contribuiriam para a cultura mundial. Os monumentos europeus não poderiam ser ofuscados, mas os EUA tinham monumentos terrestres, maravilhas naturais do oeste compensando a ausência de cidades americanas antigas e tradições aristocráticas. Como justificativa para criação do parque destacou-se a importância de suas belezas cênicas. Observe que esse tipo de preservacionismo é seletivo, na medida em que privilegia áreas que são esteticamente apelativas, segundo valores ocidentais ("grand canyons", rios caudalosos, etc). As áreas de brejos, pântanos, etc. não tinham o mesmo valor para preservação por não apresentarem a mesma "beleza sublime" (DIEGUES,1993). Destacando as palavras de Vesentini,

As escolhas sobre o que preservar, como preservar, onde preservar, etc, também não estão isentas de lutas e relações de poder (VESSETINI, 1989 p. 55).

Portanto, a criação do parque de Yellowstone foi acompanhada por um forte ideal "monumentalista" e de afirmação de poder e não apenas motivada pelo ambientalismo.

A criação de Yellowstone e de outros parques mundo afora, caracteriza também o início de uma fase em que o estado passa a ser o maior responsável pelo processo de implantação e gestão territorial das unidades de conservação, visando o benefício público. Além de implementar mecanismos de criação (demarcação, desapropriações, indenizações, solução de questões fundiárias, etc), tem que promover a gestão administrativa (destinação de verbas orçamentárias, contratação e treinamento de funcionários, edificações, infra-estrutura, fiscalização, etc). Logo, passa a ser o grande agente interventor da organização territorial das unidades de conservação, planificando e regulando as atividades em seu interior. E um dos exemplos mais concretos relacionados com a territorialização do espaço citada por Raffestin, cujo ator sintagmático é o estado.

\section{UNIDADES DE CONSERVAÇÃO E DESTERRITORIALIZAÇÃO DE GRUPAMENTOS HUMANOS: CONFLITOS E AVANÇOS}

Essa forma de intervenção estatal na criação de espaços (ou territórios) protegidos, também foi responsável pelo processo de desterritorialização de vários grupamentos sociais, tradicionais ${ }^{5}$ ou não, que lá viviam antes da criação das unidades de conservação. Em países africanos, por exemplo, McCormick (apud BRITO, 1998a) assinala que a criação de parques pelo governo angariou a antipatia das populações locais para o conceito de proteção da vida selvagem, pois os animais estavam sendo protegidos por razões não práticas e sem consideração para com os direitos tradicionais de caça.

Haesbaert assinala que o processo de desterritorialização no mundo contemporâneo, pode ser

5 Segundo, Diegues, um aspecto importante na definição das culturas tradicionais é a existência de sistemas de manejo marcados pelos ciclos naturais, sua exploração dentro da capacidade de recuperação das espécies de plantas e animais. Esses sistemas revelam a existência de um complexo conjunto de conhecimentos adquiridos pela tradição herdada dos mais velhos, de mitos e simbologias que levam à manutenção e ao uso sustentado dos ecossistemas. O território é também o local das representações e do imaginário mitológico dessas sociedades tradicionais. Os ciclos da natureza (vinda de cardumes de peixes, abundância nas roças, etc) são associados a explicações míticas ou religiosas. 
analisado sob diferentes enfoques. A contraposição entre fixidez (território) e fluidez (rede) tem sido a principal referência de análise. A primeira delas, já foi apresentada ao longo desse trabalho, ou seja, o território valorizado de acordo com a sua base material mais fixa, importante para a compreensão do territorialismo das comunidades biológicas e sociedades tradicionais. A segunda se refere à emergência de uma sociedade "em rede" (CASTELLS apaud HAESBDERT, 2002) em detrimento de uma sociedade "territorial" Castells contrapõe um "espaço de fluxos" a um "espaço de lugares". Enquanto o mundo dos territórios aparece de forma mais enraizada e estável, contrapõe-se um mundo das redes, mais instável e fluido. Existem diferentes leituras sobre esse assunto como as que procuram radicalizar mais a questão afirmando que as redes contrapõem-se ao território. Outras afirmam que território e rede formam um binômio em que a rede pode tanto ser um elemento fortalecedor, interno aos territórios (redes viárias e de comunicações como base de integração no território nacional), quanto um elemento que se projeta para fora do território, promovendo a sua desestruturação, logo desterritorialização (HAESBAERT, 2002). Em terceiro lugar, existem os territorialistas, cada vez mais raros, que defendem a idéia que a rede está totalmente subordinada ao território e este se confunde com o espaço geográfico, já que toda relação social seria também uma relação territorial. A rede é vista participando apenas de processos territorializadores, na medida que ajuda a integrar o território, visto sempre como sendo mais estável e enraizador.

Acredito que a segunda abordagem é a mais apropriada, sem, entretanto, querer excluir a terceira. A primeira, até pelo seu aspecto excludente, me parece a menos adequada para avaliação da multiplicidade de situações que se apresentam no mundo atual, incluindo aí as mais tradicionais e as mais modernas.

Podemos afirmar que a organização e realização de diversas conferências e congressos mundiais sobre a questão das unidades de conservação, estimulou a formação de uma "rede próterritórios de conservação". Ela teve como primeira finalidade, garantir a preservação dos territórios naturais pelo mundo, na forma dos habitats e ecossistemas. Com as pesquisas científicas e crescentes preocupações com a redução da biodiversidade global, novas motivações surgiram. Nesse momento, a dimensão biológica do território assume um papel relevante, mas isso só se consolidaria na medida em que os governos e a sociedade se conscientizassem sobre a questão. A criação legal de parques e reservas não é garantia de cumprimento de seu papel, mesmo que ele esteja restrito apenas à preservação de belezas naturais ou santuários da vida silvestre. Por outro lado, a formação dessa mesma rede, como já foi mencionado, também gerou um processo de desterritorialização de grupos sociais por conta da criação das unidades de conservação públicas. O modelo americano de criação de parques ocorreu sobre áreas praticamente vazias e as culturas indígenas estavam desorganizadas. Entretanto, no Terceiro Mundo, os ecossistemas eram ocupados por populações tradicionais que os mantiveram pouco alterados devido à forma não capitalista de uso. Nesses ecossistemas foram criadas as unidades de conservação, desconsiderando-se completamente as peculiaridades étnicas de cada continente, país, região ou lugar.

A desterritorialização de grupamentos sociais enquanto impacto negativo da criação das unidades de conservação, só começou a ser considerada de forma mais concreta, a partir dos anos 70, com o surgimento do Programa das Nações Unidas para o Meio Ambiente (PNUMA) e o Programa Homem e Biosfera (MAB) da UNESCO, logo após a Conferência de Estocolmo (1972). Consolidou-se, efetivamente, a partir do III Congresso Mundial de Parques Nacionais, realizado em 1982 (Bali — Indonésia), quando houve uma evolução na abordagem do conceito de Parque Nacional, sobretudo em relação à integração com o desenvolvimento sócio-econômico. Ficou estabelecida a estratégia de que os parques nacionais e outras unidades de conservação só teriam sentido com a elevação da qualidade de vida da população dos países em vias de desenvolvimento, sem o que ela seria forçada a explorar, de forma predatória, os recursos naturais. Reafirmaram-se os direitos das sociedades tradicionais e sua determinação social, econômica, cultural e espiritual. É recomendado aos responsáveis pelo planejamento e manejo das áreas protegidas que investiguem e utilizem as habilidades tradicionais das comunidades afetadas pelas medidas conservacionistas e que as decisões de manejo ocorram de forma conjunta, considerando a variedade de circunstâncias locais. O sistema de classificação adotada 
pela UICN em 1994, incluiu os povoamentos indígenas em todas as categorias de áreas protegidas, possibilitando o resgate das terras pelos povos inicialmente excluídos.

No Brasil, segundo a Lei 9.985, de 18 de julho de 2000 (SNUC), essa questão ainda é controvertida, pois a presença de populações tradicionais dentro das unidades de conservação só está prevista no interior das Reservas Extrativistas e de Desenvolvimento Sustentável. Nas demais categorias, especialmente as de uso mais restritivo como Parques, Reservas e Estações Ecológicas, ela não é admitida. A polêmica em torno desse tema é produto de acirrados embates entre posturas mais preservacionistas e os etnoecologistas ${ }^{6}$, mas que não será objeto de discussão nesse momento.

Queremos destacar aqui um fato da maior importância, em escala nacional, que foi formação da Rede Nacional Pró-Unidades de Conservação, sediada em Curitiba/PR. Criada em 1996 por um grupo de organizações não-governamentais conservacionistas, decidiram somar esforços para fazer frente ao estado crítico de abandono das Unidades de Conservação brasileiras e à omissão governamental com relação à sua missão de protegê-las. Segundo sua Carta de Princípios, a missão da Rede é contribuir para proteger, fortalecer, aprimorar e ampliar o conjunto de Unidades de Conservação, especialmente as de proteção integral, através da mobilização, da ação política coordenada e do apoio mútuo entre as organizações conservacionistas não governamentais. Ela conta com 18 ONGs associadas em 10 estados brasileiros do sul, sudeste, centro-oeste e nordeste. Sob sua coordenação, organizou os I, II e III Congressos Brasileiros de Unidades de Conservação, realizados em Curitiba (1997), em Campo Grande (2000) e Fortaleza (2002), respectivamente. A participação nesses congressos aumentou de 600 (1997) para $1250(2002)^{7}$ participantes denotando um interesse crescente da área acadêmica e das demais organizações, principalmente as não governamentais, sobre a questão.

A abordagem teórica do tema nos remete às considerações feitas por Haesbaert, onde o território e a rede formam um binômio em que a rede pode se constituir em elemento fortalecedor ou desestruturador das territorialidades. Tanto a rede mundial, centralizada nas ações da ONU/UICN, quanto a Rede Pró-UCs brasileira, têm procurado fortalecer as comunicações entre os vários setores envolvidos com a criação e gestão das unidades de conservação (governos, ONGs, iniciativa privada e sociedade em geral), cada uma a seu tempo e dentro de sua escala de atuação. Sem aprofundar a discussão sobre a filosofia de atuação dessas redes, deve-se reconhecer que elas têm contribuído para o debate do tema possibilitando a participação dos vários setores interessados direta e indiretamente.

Não se pode ignorar nessa rápida exposição, o papel do crescimento do ambientalismo mais politizado no Brasil, especialmente a partir da segunda metade da década de 80. Mesmo considerando que os movimentos em defesa da natureza ainda são originados e mais difundidos nas populações urbanas e de classe média, não se pode negar a sua importância na ampliação da cultura ambientalista nacional (PÁDUA, 1987).

\section{JUSTIFICATIVAS PARA A CONSERVAÇÃO DA BIODIVERSIDADE E A CRIAÇÃO DE UNIDADES DE CONSERVAÇÃO: AGREGAÇÃO DE VALORES}

Procuraremos agora discorrer sobre outra questão fundamental. Por quê existem unidades de conservação e que motivos justificam o fortalecimento de suas territorialidades?

Ao longo da história, inúmeros registros de atitudes humanas expressam o reconhecimento da necessidade de estabelecer o controle do homem sobre o próprio homem, protegendo a natureza, seja por questões mais práticas de exploração de recursos naturais, seja por crenças religiosas abstratas. Independentemente dos debates políticos e acadêmicos que se processam, esse controle ocorreu e continua ocorrendo (MILANO, 2002). Visando dar suporte a essa discussão, acredito que um dos temas fundamentais de debate esteja na agregação de "valor" ao espaço e, por

6 Nesse debate, os etnoecologistas consideram injusto e antiético a remoção das populações tradicionais de seu local de residência, afirmando que elas garantem a biodiversidade e não há crescimento populacional (Diegues).

7 Dados fornecidos pela Rede Nacional Pró-Unidades de Conservação em novembro de 2002 
conseguinte, aos recursos espaciais, onde temos a questão da conservação da biodiversidade.

Em qualquer época e em qualquer lugar, a sociedade, em sua própria existência, valoriza o espaço. As sociedades humanas para reproduzirem as condições de sua existência, estabeleceram relações vitais com o seu espaço. Segundo a ótica Marxista (apud MORAES, e DA COSTA, 1987), o trabalho é o mediador universal dessa relação e fonte do valor e da valorização. Cada modo de produção terá sua forma particular de valorização. A relação sociedade-espaço é uma relação valor-espaço, pois é substantivada pelo trabalho humano. Por isso, a apropriação de recursos do próprio espaço, a construção de formas humanizadas sobre o espaço, a conservação de seus atributos naturais e culturais, tudo isso representa criação de valor.

Mesmo no caso das áreas "virgens", sob certos aspectos, representam para a sociedade, em geral, e para o capitalismo, em particular, ou reservas territoriais (com todos os recursos ali contidos) estratégicas para valorização futura, ou reservas naturais sob a tutela do Estado, que procura preservar-lhes o seu aspecto natural primitivo.

Como conseqüência geral desse processo, fala-se numa "segunda natureza" , ou seja, a natureza humanizada, modificada e transformada em objeto geral, não só do trabalho, mas da produção capitalista, em particular. Essa "segunda natureza" contrapõe-se historicamente àquela primeira natureza dos tempos remotos.

Seguindo esse critério, as unidades de conservação são componentes dessa categoria. A criação de um parque pelo poder público significa a produção de um território cujos objetivos estão voltados para a proteção de atributos naturais valorizados pela sociedade no presente e para as gerações futuras.

O desenvolvimento recente de novas disciplinas associadas à conservação da natureza, entre elas a Biologia da Conservação ${ }^{8}$ e a Economia Ecológica ${ }^{9}$, trouxe, e ajudou a sistematizar, novos argumentos relacionados com a atribuição de valores aos bens naturais e com a sua conservação. No âmbito da Economia Ecológica associada com a biodiversidade das espécies, foram desenvolvidas várias abordagens para atribuir valores econômicos à variabilidade genética, às espécies, às comunidades e aos ecossistemas. Numa delas, desenvolvida por McNeely (1998) e McNeely et al. (apud PRIMACK e RODRIGUES), existem os valores diretos e os indiretos.

\section{Valores econômicos diretos}

Os produtos que são diretamente colhidos e usados pelas pessoas podem ser divididos entre Valor de Consumo e Valor Produtivo:

Valor de Consumo - mercadorias, como lenha e animais de caça, consumidos internamente mas que não aparecem nos mercados nacionais e internacionais. Usados na subsistência, não são contabilizados nos cálculos dos PIBs nacionais porque não são comprados nem vendidos. Nas zonas rurais, quando as pessoas dependem desses produtos e não podem obtê-los (por motivos de degradação ambiental, super exploração de recursos, criação de uma reserva protegida), haverá necessidade de migração para outro lugar. E o caso das sociedades tradicionais em países em desenvolvimento dependentes diretamente de madeira, vegetais, frutas, carne, medicamentos e materiais de construção. Farnsworth (apud PRIMACK e RODRIGUES) cita que cerca de $80 \%$ da população mundial ainda utiliza medicamentos tradicionais derivados de plantas e animais.

Valor Produtivo - é atribuído aos produtos extraídos do ambiente e vendidos no comércio nacional ou internacional. Eles têm seu valor estabelecido por padrões econômicos aplicados ao preço pago no primeiro ponto de venda, menos os custos desse ponto e não pelo seu custo final no varejo. Como conseqüência, o que parece ser um produto final de menor importância pode ser

8 A Biologia da Conservação surgiu ao longo dos últimos 10 anos, sendo uma espécie de fusão entre teoria, pesquisa, experiências de projetos aplicados e de políticas públicas. As preocupações com a perda da biodiversidade em todo o mundo e a busca de alternativas de sustentabilidade, estão entre seus principais objetivos. (PRIMACK, e RODRIGUES)

9 O termo Economia Ecológica refere-se a esforços colaborativos para estender e integrar o estudo e o gerenciamento do "lar da natureza" (ecologia) e o "lar da humanidade" (economia) (CONSTANZA, apud, MAY, 1995). A economia ecológica tem como parâmetros gerais de trabalho os limites dos ecossistemas e a valoração dos custos ambientais, assim como os benefícios de caminhos alternativos de desenvolvimento (MAY, 1995). 
o ponto de partida de produtos industrializados de grande valor. Vários produtos são extraídos do ambiente e depois vendidos no mercado e entre os de maiores vendas estão a lenha, madeira para construção, peixes e mariscos, plantas medicinais, frutas e vegetais, carne e pele de animais silvestres, fibras, ratam, mel, cera de abelha, tinturas naturais, algas marinhas, forragem animal, perfumes naturais, cola e resina de plantas.

Algumas espécies nativas de plantas e animais aproveitadas localmente, podem ser produzidas em plantações e fazendas e outras podem ser cultivadas em laboratório. Estas colônias, em geral, provém de áreas silvestres e são uma fonte de material para melhoramento genético de populações domesticadas. No caso das plantas, uma espécie ou variedade selvagem pode fornecer um gene especial que confira resistência a pestes ou aumento de produção. Este gene precisa ser obtido na natureza apenas uma vez e poderá ser incorporado às espécies cultivadas e ser guardado num banco de genes. O contínuo melhoramento genético de plantas cultivadas é necessário para melhorar o rendimento e resguardá-las dos insetos resistentes à pesticidas e aos fungos, vírus e bactérias, cada vez mais virulentos (HOYT, apud PRIMACK e RODRIGUES).

Outro aspecto importante na preservação da biodiversidade e das áreas silvestres é a possibilidade de aproveitamento de agentes de controle biológico natural (JULIEN, apud PRIMACK e RODRIGUES). O controle de uma espécie nociva é feito através do manejo de uma outra espécie oriunda de ambientes silvestres.

O mundo natural também é importante fonte de novos medicamentos. Nos EUA, $25 \%$ das receitas usadas contém ingredientes derivados de plantas. Antibióticos como a penicilina e tetraciclina, provêm de fungos e outros microrganismos (FARNSWORTH, 1988; EISNER, 1991, apud PRIMACK e RODRIGUES). Animais venenosos como cobras, artrópodes e espécies marinhas são fontes ricas de elementos químicos de aplicações médicas valiosas. Os 20 fármacos mais utilizados nos EUA são todos baseados em elementos químicos primeiramente identificados em produtos naturais. Por isso, programas internacionais têm propiciado incentivos financeiros a países para proteger seus recursos naturais e áreas silvestres.

\section{Valores Econômicos Indiretos}

Estes, estão associados a processos ambientais e serviços proporcionados por ecossistemas que geram benefícios econômicos sem que haja qualquer forma de exploração econômica direta. Por não se constituírem em mercadorias ou serviços que possam ser contabilizadas no sentido econômico usual, não aparecem nas estatísticas nacionais como o PIB ou PNB. Entretanto, a longo prazo, podem ser cruciais para a disponibilidade de recursos dos quais as economias dependem. Se os ecossistemas naturais não estiverem disponíveis para propiciar tais benefícios, fontes alternativas devem ser encontradas, freqüentemente a altos custos.

Podem ser:

Valor não consumista - as comunidades biológicas fornecem uma grande variedade de "serviços ambientais" que não são consumidos pelo uso, como por exemplo: o valor de insetos que fazem a polinização das plantações de maracujá, figo, abacate e outras. Esse valor poderia ser estimado através do cálculo sobre o quanto a plantação tem seu valor aumentado através dessa ação ou sobre o quanto o agricultor teria que pagar se tivesse que alugar colméias e algum apicultor. Esse caso é relativamente simples, mas existem outros bem mais difíceis de estimar, principalmente em escala global:

1. Produtividade dos ecossistemas - a captação de energia solar armazena biomassa que é aproveitada de forma direta ou indireta pelos humanos através das cadeias alimentares. A captação de $\mathrm{CO}_{2}$ e liberação de $\mathrm{O}_{2}$ fazem parte do processo.

2. Proteção da água e recursos do solo - proteção de bacias hidrográficas, controle de enchentes ou secas e manutenção da qualidade da água.

3. Controle climático - moderação do clima local, regional e até global. Manutenção de processos climáticos essenciais como o ritmo das chuvas. Manutenção da qualidade do ar atmosférico. 
4. Dejetos - degradação e imobilização poluentes como metais pesados, pesticidas e esgotos jogados pelo homem.

5. Relacionamento entre espécies - Muitas espécies aproveitadas e apreciadas pelo homem dependem de outras espécies silvestres para continuação de sua existência. Logo, o declínio de uma espécie nativa pode acarretar no declínio de uma espécie utilizada economicamente.

6. Recreação e ecoturismo - o enfoque central do lazer é o prazer não consumista advindo da natureza através de atividades diversas. Esse valor é, às vezes, chamado de "valor de amenidade", e está associado com a conservação dos espaços nativos. Esse valor pode ser estimado pela movimentação de pessoas que participam de atividades e os recursos financeiros auferidos com viagens, hospedagens, restaurantes, bilheterias, equipamentos, etc.

7. Valor Educacional e Científico - Um número considerável de pesquisadores e amadores engaja-se em observações ecológicas que tem valor de uso não consumista na forma de emprego e dinheiro gasto com produtos e serviços. Atividades científicas fornecem benefícios econômicos para as áreas próximas de reservas protegidas e seu valor real está na possibilidade de aumentar o conhecimento humano, melhorar a educação e enriquecer a experiência humana.

8. Indicadores ambientais - espécies particularmente sensíveis às toxinas químicas podem servir como "sistema de alerta" para monitoramento da saúde do ambiente, servindo até como substitutos de equipamentos caros de detecção. (líquens, moluscos, algas, etc)

Valor de opção - é o potencial que uma espécie tem para fornecer um benefício econômico para a sociedade em algum momento no futuro. Assim como mudam as necessidades da sociedade, a solução de alguns problemas pode vir com animais ou plantas ainda não estudados e considerados previamente. A indústria da biotecnologia tem descoberto novas maneiras de reduzir a poluição, desenvolver processos industriais e combater doenças que ameaçam a saúde humana. Resguardar ambientes silvestres nativos possibilita a preservação de material genético potencial (bancos genéticos) para futuras descobertas. Se uma espécie se extingue antes de ser descoberta, pode-se ter um grande prejuízo global, mesmo que outras permaneçam preservadas.

\section{A dimensão ética}

Uma abordagem complementar para proteção da diversidade biológica é a mudança de valores de nossa sociedade materialista. Muitas culturas tradicionais têm coexistido com sucesso com o seu ambiente há milhares de anos, devido à ética social que encoraja a responsabilidade pessoal e uso eficiente de recursos. Além dos argumentos econômicos, não se pode prescindir de aspectos éticos. Muitas religiões, filosofias e culturas se utilizam de fortes argumentos éticos e que, em geral, são facilmente entendidos pelo grande público. Dourojeanni (apud MILANO, 2002) declara que

a proteção da natureza não se faz apenas para garantir a nossa sobrevivência, tampouco como objetivo principal de lucrar com ela; a proteção da natureza é antes de tudo uma necessidade moral essencial ...é parte de nossa identidade como habitantes da terra (MELANO, 2002).

Os argumentos econômicos ainda estão sendo desenvolvidos e, por vezes, são ineficientes e imprecisos, logo não convincentes. Independentemente de seu valor econômico atual ou futuro, existem alguns princípios gerais baseados no valor intrínseco das espécies (PRIMACK e RODRIGUES):

1. O direito de existência das espécies independentemente de seu valor de uso ou troca;

2. Há uma interdependência entre as espécies que deve ser respeitada;

3. A sociedade tem a responsabilidade de proteger a terra no presente e para as gerações futuras; 
4. O respeito pela vida e diversidade humana é compativel com o respeito pela diversidade biológica;

5. A natureza tem um valor estético e espiritual que transcende seu valor econômico;

6. A diversidade biológica é necessária para determinar a origem da vida.

Resumindo, podemos afirmar que todos os níveis da diversidade biológica são necessários para a sobrevivência contínua das espécies e das comunidades naturais e, por sua vez, todos são importantes para a espécie humana. A diversidade das espécies fornece recursos e alternativas de recursos às pessoas. Por exemplo, a diversidade genética é necessária para qualquer espécie manter a vitalidade reprodutiva, a resistência às doenças e a habilidade de se adaptar às mudanças. Os serviços ambientais proporcionados pelos ecossistemas (controle de enchentes, oferta de água, manutenção dos microclimas, proteção contra a erosão, etc) dependem do equilíbrio das relações no interior das comunidades biológicas. Além da importância de se compreender tecnicamente o papel dessas relações, faz-se necessário a incorporação cultural (agregação de valor) dessa dimensão às práticas sociais da humanidade.

\section{POLÍTICAS PÚBLICAS}

\section{Aspectos conceituais e a questão ambiental brasileira}

Entre as inúmeras tentativas de se estabelecer uma definição a respeito do significado de políticas públicas, destacamos algumas assinaladas por Pal (apud AMARAL, et al, 2002):

Uma política pode ser considerada como um grupo de ações ou "não ações" em contraposição a decisões ou ações específicas. Este grupo de ações tem que ser percebido e identificado pelo analista em questão;

Uma série de decisões interrelacionadas tomadas por um ator político ou grupo de atores políticos objetivando a seleção de objetivos e meios de atingi-los dentro de uma situação especifica;

Política Pública é tudo o que os governos escolhem fazer ou não fazer. (PAL, apud AMARAL, 2002)

Esse mesmo autor estabelece uma distinção entre decisões e políticas. As primeiras são tomadas todos os dias e em grande quantidade, muitas vezes como simples reação às circunstâncias. As políticas públicas se situam acima das decisões e, geralmente, resultam de um planejamento. Se considerarmos, entretanto, o coletivo de decisões ao longo do tempo, podemos identificar as características de uma política (REIS \& MOTTA, apud AMARAL).

Vianna Jr. entende política pública como

uma ação planejada do governo que visa, por meio de diversos processos, atingir alguma finalidade. Esta definição, agregando diferentes ações governamentais introduz a idéia de planejamento, de ações coordenadas. Entretanto, as ações classificadas como políticas públicas são realizadas por diferentes organismos governamentais, nem sempre articulados entre si. (VIANNA, JR., apud AMARAL, 2002)

Moraes (1994), assinala que as políticas públicas podem ser agrupadas em três grandes segmentos:

1. políticas econômicas, incluindo neste grupo as políticas cambial, financeira e tributária;

2. políticas sociais, englobando as políticas de educação, saúde e previdência; e,

3. políticas territoriais, que compreende políticas de meio ambiente, urbanização, regionalização e de transportes.

Em linhas gerais, entendemos que política pública pode ser definida como tudo o que o 
governo faz, mas também o que não faz, já que a ausência de ação reflete um baixo nível de importância agregada a determinados temas.

Em relação à questão ambiental no Brasil, pode-se perceber que, historicamente, sempre houve um grande distanciamento entre as políticas públicas de desenvolvimento econômico e as de proteção ambiental, o que contribuiu para o elevado grau de deteriorização dos ecossistemas do território nacional.

Segundo Neder (2001),

...antes de 1981, predominava no Estado brasileiro ora o tratamento geopolitico de administração setorial dos recursos naturais (florestas, águas, pesca, terras), ora o do conservacionismo/preservacionismo de caráter biocêntrico (patrimônio natural em áreas protegidas)" (p. 248). Esse tratamento é denominado pelo autor de "regula ção pública ambiental desenvolvimentista". (NEDER, 2001)

Segundo Neder, tendo iniciado sob a ditadura de Vargas e o Estado Novo (1930-1945), prosseguindo dessa forma na redemocratização em 1946, do nacionaldesenvolvimentismo (19461964), esgota-se no período desenvolvimentista dos governos militares (1964-1984).

As tentativas de reformulação desse modelo político, diga-se de passagem altamente segregador entre meio ambiente e sociedade, datam dos anos 80 , com a legislação formulada em torno da Política Nacional do Meio Ambiente (PNMA). A crise do Estado desenvolvimentista, entretanto, prejudicou os esforços de abertura de agências governamentais no campo ambiental nos anos 80, após o PNMA. A crise praticamente paralisou o funcionamento das agências e inviabilizou a realização de um novo arranjo político-institucional, devido à manipulação da receita orçamentária, desacertos na descentralização tributária após 1988, além de grandes dificuldades na coordenação de diferentes campos de políticas públicas.

Como observa:

As dificuldades acabaram tornando desestimulante a ação politica sobre a questão sócioambiental, simplesmente porque ela é percebida como excessivamente complexa, pouco afeita a soldar interesses partidários e construir alianças. (NEDER, 2001)

O autor assinala que atualmente não existe um desenho efetivo para tais políticas, ou um novo modo de regulação nas políticas públicas ambientais brasileiras. Existe uma "transformação inconclusa" de políticas setoriais datadas do Estado Novo e do período autoritário, plasmada na PNMA e na Constituição de 88 , à espera de realização por meio de coalizões políticas dos interesses que provocam essa paralisia. As ações ambientais mais efetivas continuam sendo desenvolvidas por outros atores e agências públicas (saneamento, obras e saúde pública) do que pela área ambiental do governo (nos três níveis). Neste sentido, o PNMA é uma criatura disforme: nasceu sob a percepção acerca da importância do tema "ecologia/meio ambiente" mas que não ganhou eficácia ou vida própria por meio do Estado sobre a própria sociedade. O que tem prevalecido é o tratamento fiscalizatório ditado pela preservação e conservação clássicas dos recursos naturais (NEDER).

$\mathrm{O}$ autor destaca ainda a necessidade se traçar um desenho político onde prevaleça a interdependência das ações setoriais tradicionais (saneamento, recursos hídricos, saúde pública, educação, geração de renda no campo e nas cidades) com as ações ambientais, denominada de "dimensão da transversalidade setorial e de niveis de poder".

\section{Políticas públicas e as unidades de conservação no Brasil}

No caso específico das unidades de conservação, as decisões tomadas pelo governo podem, aparentemente, indicar manifestação de importância em relação ao tema. Entretanto, quando identificamos a ausência de decisões suplementares, e necessárias ${ }^{10}$, para o seu efetivo 
funcionamento, observamos que as políticas públicas nesse setor ainda não manifestam uma valorização efetiva. No Brasil, a criação de unidades de conservação foi iniciada nos anos 30, teve um incremento significativo no final dos anos 50 e 60 , e posteriormente, nos anos 80 , como mostra a figura 1.

Figura 1 _ Área acumulada das Unidades de Conservação Federais por tipo de uso (1930 — 2002)

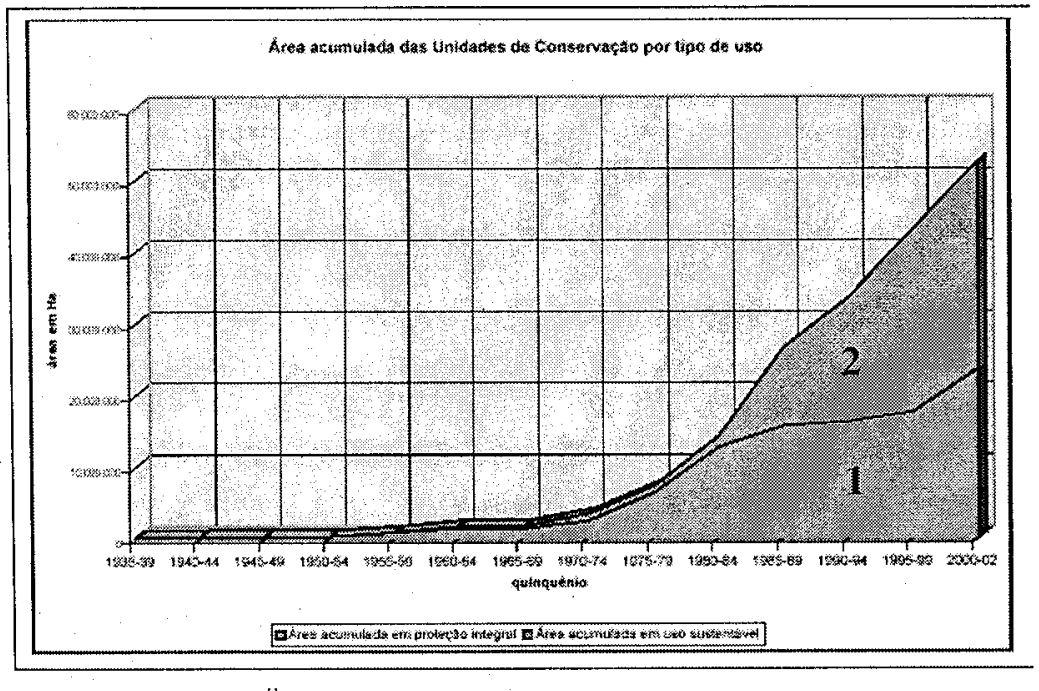

Legenda:

1 - Unidades de proteção integral

2 - Unidades de uso sustentável

Fonte : IBAMA (2002) $)^{11}$

Mesmo com todo o incremento no número e na extensão total de áreas protegidas, ainda existem inúmeros problemas em relação à situação administrativa e gerencial. Embora tenha havido uma grande evolução em relação à legislação que rege a questão, Brito (2000b) assinala que os problemas de conservação das áreas de proteção brasileiras estão vinculados a:

> falta de condições de infra-estrutura para efetiva implantação da unidades (recursos humanos e financeiros, capacidade administrativa, elaboração e execução de planos, fiscalização, etc);

$>$ indefinição quanto à propriedade das terras e desapropriações;

$>$ contexto histórico da criação das unidades e conseqüente representatividade dos biomas (área total protegida e condições de proteção); e

$>$ conflitos com populações (do interior e entorno).

Pádua (2002) faz diversas críticas à forma como se tem criado unidades de conservação no Brasil em todos os níveis de governo. Um dos aspectos é a proliferação de unidades sem base técnica e, às vezes, sem necessidade. Interesses políticos locais ou apenas interesses pessoais de representantes políticos têm levado a práticas de inauguração

de unidades de conservação sem estudos prévios, sem planejamento, sem consulta pública, sem recursos e menos ainda para implantação ou manejo(PÁDUA, 2002).

Em muitos casos esses eventos coincidem com a celebração de datas comemorativas como o Dia Mundial do Meio Ambiente.

Uma segunda crítica abrange a implantação de unidades de conservação em categorias inadequadas. Unidades de uso restrito como reservas e estações ecológicas são criadas em locais onde seria melhor implantar parques, gerando conflitos com as comunidades locais. A autora assinala que isso pode ser atribuído à falta de estudos prévios e, também, por desconhecimento do significado das categorias e possibilidades de uso e manejo das unidades de conservação.

comunidades residentes no interior e no entorno das UCs; elaboração de planos diretores de gestão; alocação de verbas e recursos humanos e outros. 
Em outras situações tem sido observado que as áreas das unidades são insuficientes (muito pequenas) para atender à preservação da biodiversidade.

Os usos previstos para as unidades de conservação não têm sido planificados e incentivados através de investimentos e parcerias com outros setores (universidades, centros de pesquisa, ONGs e iniciativa privada) e as áreas permanecem abandonadas ou com baixo aproveitamento em relação ao turismo, práticas educacionais e pesquisas científicas.

Um dos aspectos assinalados por Pádua (2002) é a necessidade de inserção das unidades de conservação no processo de desenvolvimento econômico local, como já acontece em outros países. Portanto, as políticas públicas em relação às áreas protegidas precisam integrar-se às demais políticas tradicionalmente setoriais como desenvolvimento científico e tecnológico (biotecnologia), turismo e lazer, educação, desenvolvimento local e regional, além de outras, e não ficar simplesmente atreladas a determinado ministério ou secretaria de governo.

Mesmo com os avanços, o desenho atual (e histórico) das políticas públicas brasileiras em relação. às unidades de conservação, só tem contribuído para o aumento da segregação e, também, por uma certa banalização do tema.

\section{CONSIDERAÇÕES FINAIS}

Talvez a maior de todas as dificuldades em se discutir a temática das unidades de conservação, esteja no emprego das múltiplas abordagens sobre o conceito de território de forma integrada. Por vezes, algumas dessas abordagens, especialmente aquelas envolvidas com as relações sociais (políticas, antropológicas, geográficas, etc) acabam excluindo ou promovendo dicotomizações, conforme o olhar daqueles que as adotam. Com base no que foi apresentado, acredito que todas as perspectivas sobre o conceito de território precisam convergir e interagir para que o tema seja convenientemente tratado.

A criação de uma unidade de conservação requer uma bagagem de conhecimentos amplos e específicos sobre a biologia e ecologia das espécies, portanto sobre seus nichos, territórios e territorialidades. Entretanto, esse processo depende da agregação de valores mensuráveis e não mensuráveis motivadores da própria ação de conservar, pois os atores da conservação fazem parte da própria sociedade. Sem um sentido ideal-simbólico que motive o "querer conservar", a prática não se concretiza. A valorização do processo de conservação da natureza, contemporaneamente, é conseqüência do crescimento do ambientalismo mundial apoiado nas contradições produzidas pela própria expansão do capitalismo. Ele busca, em suas múltiplas perspectivas, alternativas menos agressivas de desenvolvimento sócio-ambiental, sustentabilidade e garantia de perpetuação da biodiversidade. A expansão do ambientalismo vem se concretizando através da formação de uma rede de informações que agregam, cada vez mais, novos membros das áreas acadêmicas e do público em geral. A mesma rede tem propiciado, direta e indiretamente, e em várias escalas geográficas, a criação e expansão das unidades de conservação.

Um dos temas mais controversos de toda essa discussão, é a marginalização das populações tradicionais e outros tipos de moradores ocupantes das áreas estabelecidas como unidades de conservação devido à postura preconceituosa adotada desde a criação dos primeiros parques públicos. Felizmente, depois de muitos anos, vemos que essa questão começa a ser, pelo menos, melhor considerada.

A discussão das políticas públicas no âmbito da conservação aparece como questão central e supra-estrutural ligada à existência das áreas preservadas. No Brasil, as políticas públicas do período colonial privilegiaram o extrativismo predatório e só consideravam a possibilidade de preservação das espécies economicamente interessantes, como no caso do pau-brasil, na medida que havia um risco iminente de desaparecimento do recurso. Mesmo assim, as leis não conseguiram evitar a quase extinção da espécie, até porque os mecanismos de gestão associados com essas leis eram extremamente precários, prevalecendo o interesse privado em detrimento do público.

As políticas públicas implantadas no período republicano, especialmente ao longo dos anos 30, se caracterizavam pela administração setorizada dos recursos naturais (florestas, águas, pesca, 
terras), prevalecendo a postura preservacionista de caráter biocêntrico. Os setores de governo responsáveis por essa tarefa não dispunham de força política, muito menos administrativa e financeira, para exercer suas funções. O desenvolvimentismo econômico, acompanhado de seus indicadores, sempre foi prioritário, desconsiderando toda a base material natural que dá suporte a esse mesmo modelo. Esse desenho se repetiu ao longo das décadas subseqüentes até os anos 80 (e ainda continua).

Um novo desenho político foi formulado com a Política Nacional do Meio Ambiente (PNMA), mas não se estruturou plenamente devido às próprias dificuldades inerentes à complexidade das articulações políticas entre os múltiplos setores do próprio estado e da sociedade, em geral. Melhoraram as ações fiscalizatórias associadas com o ideal preservacionista tradicional, mas a falta de transversalidade das ações entre os setores de governo ainda continua e, certamente, continuará por algum tempo. Decisões isoladas e emergenciais por parte dos governos prevalecem sobre as políticas.

Em síntese, a garantia de manutenção de processos ecológicos essenciais importantes para a sociedade depende do estabelecimento e gestão adequada dos territórios dos ecossistemas. As políticas públicas têm ignorado, historicamente, o valor agregado à manutenção do equilíbrio dos ecossistemas, considerando apenas os valores diretos e imediatos obtidos a partir de sua exploração. As unidades de conservação têm sido criadas, mas não se tem garantido a sua territorialidade através de políticas públicas transversais. Mesmo com os avanços, elas continuam sendo "ilhas" e "santuários" de preservação das espécies e esse isolamento não garante a sua existência, nem seus fins.

Resumo: A criação de unidades de conservação é considerada como principal ação de governo cujo objetivo é a preservação e conservação da biodiversidade. A delimitação de "áreas especiais" é uma prática observada desde as sociedades mais tradicionais, sendo que em muitas delas prevalecia um sentido mítico-religioso e, ao mesmo tempo, de conservação de recursos naturais. Em outras sociedades, essa ação esteve associada com a prática de esportes de caça por parte da realeza e da aristocracia rural. Os parques públicos começaram a surgir no século XIX nos Estados Unidos, numa perspectiva de preservação das belezas cênicas e proteção dos bens naturais contra a ação deletéria da sociedade. O tema em questão é discutido à luz da categoria geográfica de território e dos processos de territorialização, utilizando-se para esse fim suas múltiplas abordagens conceituais- biológica, ecológica e social. Discute-se no trabalho os problemas da desterritorialização, em ambos os sentidos (biológico e social), além da formação das redes empenhadas no processo de criação e gestão das unidades de conservação. Houve um esforço de trazer para essa discussão uma contribuição sobre o valor agregado à conservação da biodiversidade com base em princípios de uma nova disciplina - a Biologia da Conservação. O trabalho aborda ainda aspectos conceituais sobre as políticas públicas, em geral, e sobre a influência que elas têm, especificamente, sobre a problemática das unidades de conservação no Brasil.

Abstract: The principal goal to create natural parks and biological reserves in the world is to promote the conservation of biodiversity. During long time, traditional people established "especial areas" to guarantee natural resources for the future. Others, as kings and rural aristocracy used this areas for practice sports like hunting. The first public parks were created in United States during the XIX century, to preserve the environmental features of the Yellowstone against the human explotation. In this work, I wil discuss conservation of natural areas using the territory and the territorialization concepts and their several meanings: biological/ecological and social. The biodiversity value under principles of a new discipline - Biological Conservation - is showed as contribution. Public policy is discussed at the end of work exploring some reasons of the controversy between government speech and the conservation practice in natural parks and biological reserves.

\section{BIBLIOGRAFIA}

AMARAL, W. A. N. DO, BRITO, M. C. W. DE; ASSAD, A. L. D. E MANFIO, G. P. Políticas Públicas em Biodiversidade: Conservação e uso Sustentado no País da Megadiversidade. Consultado em 21/11/2002 no site: www.hottopos.com/harvardl/politicas....publicas...em_biodiversi.htm

BENNETT, C. F. - 1983. Conservation and Management of Natural Resources in the United States. USA: John Wiley \& Sons.

BRASIL 2002.- Sistema Nacional de Unidades de Conservação da Natureza. Lei 9.985 de 18 de julho de 2000 e Decreto 4.340 de 22 de agosto de 2002. Ministério do Meio Ambiente, $2^{\mathrm{a}}$ ed. (aumentada). Brasilia.

BRITO, M. C. W. de - 1998a Unidades de conservação: intenções e resultados. $\underline{\text { In: }}$ 
Ciência Ambiental — Primeiros Mestrados. In: José Eli da Veiga(Org.). Programa de Pós Graduação da USP. São Paulo. p: 209-228.

2000b — Unidades de Conservação: intenções e resultados. São

Paulo: Annablume: FAPESP.

DIEGUES, A. C. S. - 1993 Populações Tradicionais em Unidades de Conservação: O Mito

Moderno da Natureza Intocada. Núcleo de Pesquisa sobre Populações Humanas e Áreas

Úmidas do Brasil. Série - Documentos e Relatórios de Pesquisa, $n^{\circ}$ 1, São Paulo.

FEEMA - 1992 Vocabulário Básico de Meio Ambiente. Compilado por Iara Verocai Moreira.

Rio de Janeiro, FEEMA/Petrobrás.

HAESBAERT, R. 2002- Concepções de território para entender a desterritorialização. In:

Território Territórios. Programa de Pós-Graduação em Geografia da Universidade Federal

Fluminense. Niterói, p. $17-38$.

MAY, P. H. 1995 - Economia ecológica: aplicações no Brasil. May Peter H. (org). Rio de Janeiro: Campus.

MILANO, M. S. — 2002 Por quê existem as unidades de conservação? In: Unidades de conservação: atualidades e tendências. Miguel Sereduik Milano (org.). Curitiba: Fundação O Boticário de Proteção à Natureza. p. 193-208.

Mitos no manejo de unidades de conservação no Brasil, ou a verdadeira

ameaça. In: Anais do II Congresso Brasileiro de Unidades de Conservação, 2, 2000, Campo

Grande: Rede Nacional Pró-Unidades de Conservação: Fundação O Boticário de Proteção à

Natureza, 2000, v. 1, p. 11-25

MILLER, K. R. - 1997 Evolução do conceito de áreas de proteção — oportunidades para o século XXI. In: Anais do I Congresso Brasileiro de Unidades de Conservação. Curitiba: IAP: UNILIVRE: Rede Nacional Pró Unidades de Conservação, Vol. 1: 3-21.

MORAES, A. C. R. e DA COSTA, W. M. 1987 - Geografia Crítica: A Valorização do Espaço. São Paulo: Hucitec. $2^{\text {a }}$ ed.

MORAES, A.C.R. - 1999 Meio ambiente e ciências humanas. São Paulo: Hucitec. 1994

MORSELLO, C. - 1999 Unidades de Conservação Públicas e Privadas: Seleção e Manejo no Brasil e Pantanal Mato-Grossense. In: Ciência Ambiental — Os Desafios da Interdisciplinaridade. Pedro Roberto Jacobi (Org.) Programa de Pós-Graduação da USP. São Paulo: Annablume. p. 333-358.

NARANJO, F. Z. — 2000 Geografía y ordenación del territorio. Universidad de Sevilha. Texto avulso.

NEDER, R. de T. 2001 - Por uma regulação pública ambiental pós-desenvolvimentista no Brasil. In: Meio Ambiente, desenvolvimento sustentável e políticas públicas. Clóvis Cavalcanti (org.) $-3^{\mathrm{a}}$ ed. — São Paulo: Cortez: Recife: Fundação Joaquim Nabuco, Cap. 15: $248-259$.

ODUM, E. P. 1977 - Ecologia. São Paulo. Ed. Pioneira. Ecología. $3^{\mathrm{a}}$ ed. Trad. Carlos Ottenwalder. México D.F., Interamerica, $1972.639 \mathrm{p}$.

OLIVEIRA, L. C. A. - 1999 The interaction between Park management and the activities of local people around National Parks in Minas Gerais, Brazil. Ph.D. in Geography. University of Edinburg.

PADUA, J. A. - 1987 "Natureza e Projeto Nacional. As origens da Ecologia Política no Brasil" In: Pádua, J. A. (org), Ecologia e Política no Brasil, Espaço e tempo. IUPERJ, Rio de Janeiro.

PADUA, M.T.J - 2002 Unidades de conservação: muito mais do que atos de criação e planos de manejo. In: Unidades de Conservação: Atualidades e Tendências, Miguel Sereduik Milano (org.) - Curitiba: Fundação O Boticário de Proteção à Natureza, p. 7 - 13.

PRIMACK, R. B. e RODRIGUES, E. —2001 Biologia da Conservação. Londrina: E. Rodrigues. $328 \mathrm{p}$.

QUINTÃO, A. T. B. - 1983 Evolução do conceito de Parques Nacionais e sua relação com o processo de desenvolvimento. Brasil Florestal. Brasília, n 54, p. 13 a 28. Abr-jun.

RAFFESTIN, C. 1993 - O que é território. In: Raffestin, C., Por uma Geografia do Poder, Cap. I. São Paulo: Ed. Ática., p. $143-163$. 
ROCHA, L. G. M. da - 2002 Os Parques Nacionais do Brasil e a Questão Fundiária: o caso do Parque Nacional da Serra dos Órgãos. Dissertação de Mestrado do Programa de PósGraduação em Ciência Ambiental da Universidade Federal Fluminense. Rio de Janeiro. RONCAYOLO, M. - 1986 Território. In: Enciclopédia EINAUDI, nº 8, Lisboa. Imprensa Nacional - Casa da Moeda.

UICN, CPNAP, CMMC — 1994 Directrices para las categorias de manejo de áreas protegidas. Gland. $161 \mathrm{p}$.

VESENTINI, J. W. - 1989 Geografia, Natureza e Sociedade. São Paulo: Contexto. Coleção Repensando a Geografia.

WORLD RESOURCES INSTITUTE 2001 - World Resources 2000-01. World Resources Institute and the International Institute of Environment and Development in colaboration with the United Nation Environment Programme. USA: Library of Congress International Standard. 